\title{
Tree growth, wood and bark water content of 28 Amazonian tree species in response to variations in rainfall and wood density
}

\author{
Daniela Pereira Dias ${ }^{(1)}$, Ricardo \\ Antonio Marenco ${ }^{(2)}$
}

\begin{abstract}
Pole diameter and wood density are variables commonly used in allometric equations to estimate tree biomass and carbon stocks in tropical forests. The effect of variations in tree water content on pole diameters is often disregarded in allometric equations. This study aimed to determine the effect of rainfall seasonality on tree growth, stem wood and bark water content and to assess the relationship between water content and wood density (dry mass to fresh mass volume ratio) in 120 trees from 28 species in a terra-firme rain forest in the central Amazon. In 2006, stem wood and bark water content were gravimetrically determined in the dry season (August-September) and rainy season (April-May). In the same year, growth in diameter was measured at monthly intervals in the 120 trees $(\mathrm{DBH} \geq 10 \mathrm{~cm})$ with dendrometric bands previously adapted to the tree. Mean wood water content was lower in the dry season than the rainy season. On the contrary, bark water content was higher in the dry season than in the rainy season. Wood densities higher than $0.75 \mathrm{~g}$ $\mathrm{cm}^{-3}$ were found in $64.3 \%$ of the trees. Trees with denser woods grew slower and had lower stem water content. Monthly rainfall did not affect tree growth in diameter, which was contrary to our initial expectation on the effect of rainfall seasonality on tree growth in central Amazonia. This finding supports the hypothesis that in central Amazonia, the mild dry season is not long enough to deplete soil water beyond the reach of the root system, which allows the trees to grow at quite constant rates over the year.
\end{abstract}

Keywords: Amazonia, Allometry Equations, Pole Diameter, Rainfall Seasonality
Tree diameters can be influenced by changes in stem water content (Simonneau et al. 1993, Remorini \& Massai 2003, Cermak et al. 2007), which can also affect the accuracy of biomass estimation.

Basic wood density (dry mass to fresh volume ratio) can vary among species, treeto-tree, and even among different parts of the same plant (Nogueira et al. 2008). It can vary among geographical locations and in response to changes in environmental factors such as soil fertility, temperature and rainfall (Muller-Landau 2004, Nogueira et al. 2005, Chave et al. 2006). In the Amazon basin, it is believed that wood density can give information about the successional stage of a forest on a given location (Baker et al. 2004, Nogueira et al. 2008).
(1) Forest Ecology and Ecophysiology Laboratory, Federal University of Goiás/Jataí, GO (Brazil); (2) Tree Ecophysiology Laboratory, Coordination of Environmental Dynamic, National Institute for Research in the Amazon, Manaus, AM (Brazil)

@ Ricardo Antonio Marenco (rmarenco@inpa.gov.br)

Received: Apr 15, 2015 - Accepted: Aug 24, 2015

Citation: Dias DP, Marenco RA (2016). Tree growth, wood and bark water content of 28 Amazonian tree species in response to variations in rainfall and wood density. iForest 9: 445451. - doi: 10.3832/ifor1676-008 [online 2016-01-16]

Communicated by: Vicente Rozas
Trees with high wood density have xylem conduits less prone to cavitation and embolism during the dry season (Hacke et al. 2001, Meinzer et al. 2009). They also tend to accumulate less water than those with low-density wood (Suzuki 1999, Osunkoya et al. 2007).

Variations in pole water content are mostly related to rainfall seasonality (Gibbs 1958, Chapotin et al. 2006). Fluctuations in pole diameter are associated with diurnal and seasonal changes in the water content of stem, particularly with variation in the water content of the bark, and to a lesser extent, with sapwood swelling and contraction (Zweifel et al. 2000, Remorini \& Massai 2003).

Variations in the water content of poles reflect their water-storing capacity - tree capacitance (Goldstein et al. 1998, Stratton et al. 2000, Zweifel et al. 2000), as the pole can store water to be used when the amount of water lost by transpiration exceeds the water uptake capacity of the tree (Cermak et al. 2007). It occurs, for example, during the hottest period of the day or during the dry season of the year. At night, the pole expands and throughout the day there is a progressive contraction due to decline in water content (Nortes et al. 2005, Vergeynst et al. 2014). During the dry season, the soil water content often declines, and hence it can be expected that the amount of water stored in the pole is 
also reduced in this season (less water to keep the stomata open for most of the day). Not unsurprisingly, it has been found that in some parts of the Amazon, trees grow slower in the dry season (Phillips et al. 2002, Wagner et al. 2014).

In this study we hypothesized that trees grow faster in the wet season and that bark and wood hold less water in the dry season. The aims of this study were: (1) to determine the effect of monthly rainfall on tree growth in diameter and water content of the bark and stem wood; and (2) to assess the relationship between water content and wood density in tree species of a pristine terra-firme rain forest in central Amazonia.

\section{Materials and methods}

\section{Study site, plant material and climate} parameters

Data were collected in 2006 at the Tropical Forest Experimental Station (ZF2 reserve - $\left.60^{\circ} 08^{\prime} \mathrm{W}, 2^{\circ} 36^{\prime} \mathrm{S}\right)$ National Institute for Research in the Amazon, State of Amazonas, Brazil. The vegetation is a dense terra-firme forest and the soil is an oxisol with low fertility, clay texture and $\mathrm{pH}$ of 4.2 to 4.5 (Marenco \& Vieira 2005). The regional climate is tropical humid, with an annual rainfall of $2420 \mathrm{~mm}$ (Malhi \& Wright 2004). A total of 120 trees from 28 species (3 to 12 trees per species) with DBH of 10 $\mathrm{cm}$ or greater were used in the study (Tab. 1).
Climate data were collected using a weather station Li-1401 (Li-Cor, Lincoln, NE, USA) placed at the top of a $40-\mathrm{m}$ tall observatory tower located near the study site $\left(60^{\circ} 06^{\prime} 53^{\prime \prime} \mathrm{W}, 02^{\circ} 35^{\prime} 21^{\prime \prime} \mathrm{S}\right)$. Air temperature, relative humidity (Humitter 50y, Vaisala Ov, Finlandia) and photosynthetically active radiation (PAR, LI-190SA, Li-Cor, Lincoln, NE, USA) sensors were connected to a datalogger (LI-1400, Li-Cor, Lincoln, NE, USA). Air temperature and relative humidity data were collected at 30-minute intervals and PAR data at intervals of 15 minutes. Rainfall data were collected at 14-day intervals using a conventional pluviometer positioned at the top of the observatory tower. The daily cumulative irradiance (mol $\mathrm{m}^{-2}$ day) was calculated by integrating the instantaneous PAR values over the whole day period. The monthly average of cumulative irradiance was obtained from the daily data.

\section{Wood and bark water content and wood density}

In the rainy season (April-May) and dry season (August-September) of 2006, core samples of bark and wood ( 3 to $5 \mathrm{~cm}$ inlength and $5.15 \mathrm{~mm}$ in diameter) were collected from the tree poles at $1.3 \mathrm{~m}$ from the ground surface (i.e., diameter at breast height - DBH) with an increment borer (Haglöf, Sweden) to determine water content. Stem wood and bark samples were placed into test tubes, and transported to the laboratory for determination of bark and wood fresh mass and fresh wood volume. Wood samples were placed in a forced-air oven and dried at $102{ }^{\circ} \mathrm{C}$ until constant mass (about $72 \mathrm{~h}$ ), and subsequently the dry mass was determined.

Water content $\left(W_{C}\right)$ was obtained as the difference between fresh mass (FM) and dry mass (DM) divided by the fresh mass (Osunkoya et al. 2007): $W_{c}(\%)=100 \times[(F M$ -DM)/FM]. Stem wood samples were collected from each tree in March and April of 2006 and again in April 2007 to determine wood density (dry mass to fresh wood volume ratio). An increment borer $(5.15-\mathrm{mm}$ inside tip diameter) was used to obtain the samples, as previously described. These three samples allowed to obtain a representative mean value from each tree. To avoid the potential risk of compressing the bark or wood during the core extraction and to obtain a smooth and uniform core sample, we used an increment borer with a carefully sharpened tip. Volume of the fresh wood sample was determined from the length of the sample and the inside tip diameter of the increment borer. The total length of the wood core was measured with digital calipers.

\section{Tree growth in diameter}

In all 120 sampled trees, tree diameter was measured at monthly intervals from January to December 2006, using dendrometric bands, which had been previously installed, four months before the beginning of this study. To determine the rela-

Tab. 1 - Mean \pm standard deviation of tree growth in diameter (TGD) and wood density (WD, dry mass to fresh mass volume ratio), and the range of diameter of the sampled trees at $1.3 \mathrm{~m}$ height $(\mathrm{DBH}, \mathrm{cm})$ of the 28 species used in the study. Species and their labels, the botanical family and number of sampled trees per species $(\mathrm{N})$ are also shown.

\begin{tabular}{|c|c|c|c|c|c|c|}
\hline Species & Label & Family & $\mathbf{N}$ & $\begin{array}{c}\text { TGD } \\
\left(\mathrm{mm} \text { month }^{-1}\right)\end{array}$ & $\begin{array}{c}\text { WD } \\
\left(\mathrm{g} \mathrm{cm}^{-3}\right)\end{array}$ & $\begin{array}{l}\text { DBH } \\
(\mathrm{cm})\end{array}$ \\
\hline Byrsonima duckeana W.R.Anderson & Bdu & Malpighiaceae & 4 & $0.22 \pm 0.07$ & $0.62 \pm 0.02$ & $22.5-45.7$ \\
\hline Erisma bicolor Ducke & Ebi & Vochysiaceae & 3 & $0.12 \pm 0.05$ & $0.56 \pm 0.02$ & $12.7-19.0$ \\
\hline Eschweilera bracteosa (Poepp. ex O.Berg) & Ebr & Lecythidaceae & 12 & $0.13 \pm 0.10$ & $0.83 \pm 0.01$ & $12.0-26.0$ \\
\hline Eschweilera collina Eyma & Eco & Lecythidaceae & 7 & $0.15 \pm 0.09$ & $0.79 \pm 0.01$ & $11.1-27.0$ \\
\hline Eschweilera grandiflora (Aubl.) Sandwith & Egr & Lecythidaceae & 3 & $0.13 \pm 0.06$ & $0.82 \pm 0.03$ & $19.1-46.1$ \\
\hline Eschweilera pedicellata (Rich.) S.A.Mori & Epe & Lecythidaceae & 5 & $0.08 \pm 0.07$ & $0.81 \pm 0.02$ & $12.0-48.3$ \\
\hline Eschweilera sp. & Esp & Lecythidaceae & 4 & $0.09 \pm 0.08$ & $0.82 \pm 0.02$ & $13.1-27.0$ \\
\hline Geissospermum argenteum Woodson & Gar & Apocynaceae & 4 & $0.10 \pm 0.07$ & $0.85 \pm 0.01$ & $12.0-35.9$ \\
\hline Gustavia augusta L. & Gau & Lecythidaceae & 3 & $0.07 \pm 0.08$ & $0.77 \pm 0.02$ & $15.1-20.6$ \\
\hline Inga laurina (Sw.) Willd. & Ila & Fabaceae & 4 & $0.47 \pm 0.16$ & $0.76 \pm 0.03$ & $14.1-22.5$ \\
\hline Lacistema aggregatum (P.J.Bergius) Rusby & Lag & Lacistemataceae & 3 & $0.17 \pm 0.06$ & $0.60 \pm 0.02$ & $12.5-19.0$ \\
\hline Licania canescens Benoist & Lca & Chrysobalanaceae & 3 & $0.20 \pm 0.07$ & $0.87 \pm 0.03$ & $28.0-37.0$ \\
\hline Licania micrantha Miq. & Lmi & Chrysobalanaceae & 5 & $0.13 \pm 0.07$ & $0.87 \pm 0.01$ & $14.0-34.1$ \\
\hline Mezilaurus itauba (Meisn.) Taub. ex Mez & Mit & Lauraceae & 5 & $0.07 \pm 0.05$ & $0.76 \pm 0.02$ & $10.1-21.3$ \\
\hline Micrandropsis scleroxylon (W.A. Rodrigues) W.A.Rodrigues & Msc & Euphorbiaceae & 3 & $0.10 \pm 0.07$ & $0.89 \pm 0.01$ & $28.9-40.3$ \\
\hline Micropholis guyanensis (A.DC.) Pierre & Mgy & Sapotaceae & 4 & $0.16 \pm 0.10$ & $0.71 \pm 0.01$ & $17.6-40.4$ \\
\hline Minquartia guianensis Aubl. & Mgu & Olacaceae & 3 & $0.11 \pm 0.07$ & $0.81 \pm 0.03$ & $16.1-49.8$ \\
\hline $\begin{array}{l}\text { Pourouma tomentosa subsp. apiculada (Spruce ex Benoist) } \\
\text { C.C.Berg \& Heusden }\end{array}$ & Pto & Urticaceae & 4 & $0.27 \pm 0.09$ & $0.42 \pm 0.02$ & $16.0-34.0$ \\
\hline Pouteria cladantha Sandwith & $\mathrm{Pcl}$ & Sapotaceae & 3 & $0.11 \pm 0.04$ & $0.78 \pm 0.13$ & $10.1-20.0$ \\
\hline Pouteria guianensis Aubl. & Pgu & Sapotaceae & 3 & $0.10 \pm 0.05$ & $0.89 \pm 0.02$ & $22.0-64.8$ \\
\hline Pouteria macrophylla (Lam.) Eyma & Pma & Sapotaceae & 4 & $0.17 \pm 0.06$ & $0.91 \pm 0.02$ & $14.2-44.0$ \\
\hline Pouteria sp. & Psp & Sapotaceae & 3 & $0.13 \pm 0.05$ & $0.79 \pm 0.03$ & $13.0-19.8$ \\
\hline Protium apiculatum Swart & Pap & Burseraceae & 8 & $0.11 \pm 0.04$ & $0.63 \pm 0.01$ & $10.0-30.0$ \\
\hline Protium hebetatum D.C. Daly & Phe & Burseraceae & 3 & $0.10 \pm 0.09$ & $0.58 \pm 0.02$ & $11.7-13.8$ \\
\hline Scleronema micranthum (Ducke) Ducke & Smi & Malvaceae & 4 & $0.47 \pm 0.22$ & $0.65 \pm 0.02$ & $21.9-46.9$ \\
\hline Swartzia tomentifera (Ducke) Ducke & Sto & Fabaceae & 4 & $0.13 \pm 0.04$ & $0.81 \pm 0.02$ & $11.0-34.1$ \\
\hline Tachigali venusta Dwyer & Tve & Fabaceae & 4 & $0.45 \pm 0.12$ & $0.56 \pm 0.02$ & $10.1-21.3$ \\
\hline Theobroma sylvestre Aubl. ex Mart. in Buchner & Tsy & Malvaceae & 5 & $0.07 \pm 0.04$ & $0.71 \pm 0.02$ & $11.0-15.0$ \\
\hline
\end{tabular}


Fig. 1 - Water content of wood and bark during the rainy season (black bars) and the dry season (white

bars) of 2006. Each bar denotes the mean of several trees within a species. Error bars represents the standard error of the mean. Labels and the number of trees per species are given in Tab. 1. Upper panel - rainy season: $F=2.9, p=$ 0.000 ; dry season: $F=5.3$, $p=0.000$. Lower panel rainy season: $F=2.0, p=$ 0.007 ; dry season: $F=4.1$, $p=0.000$
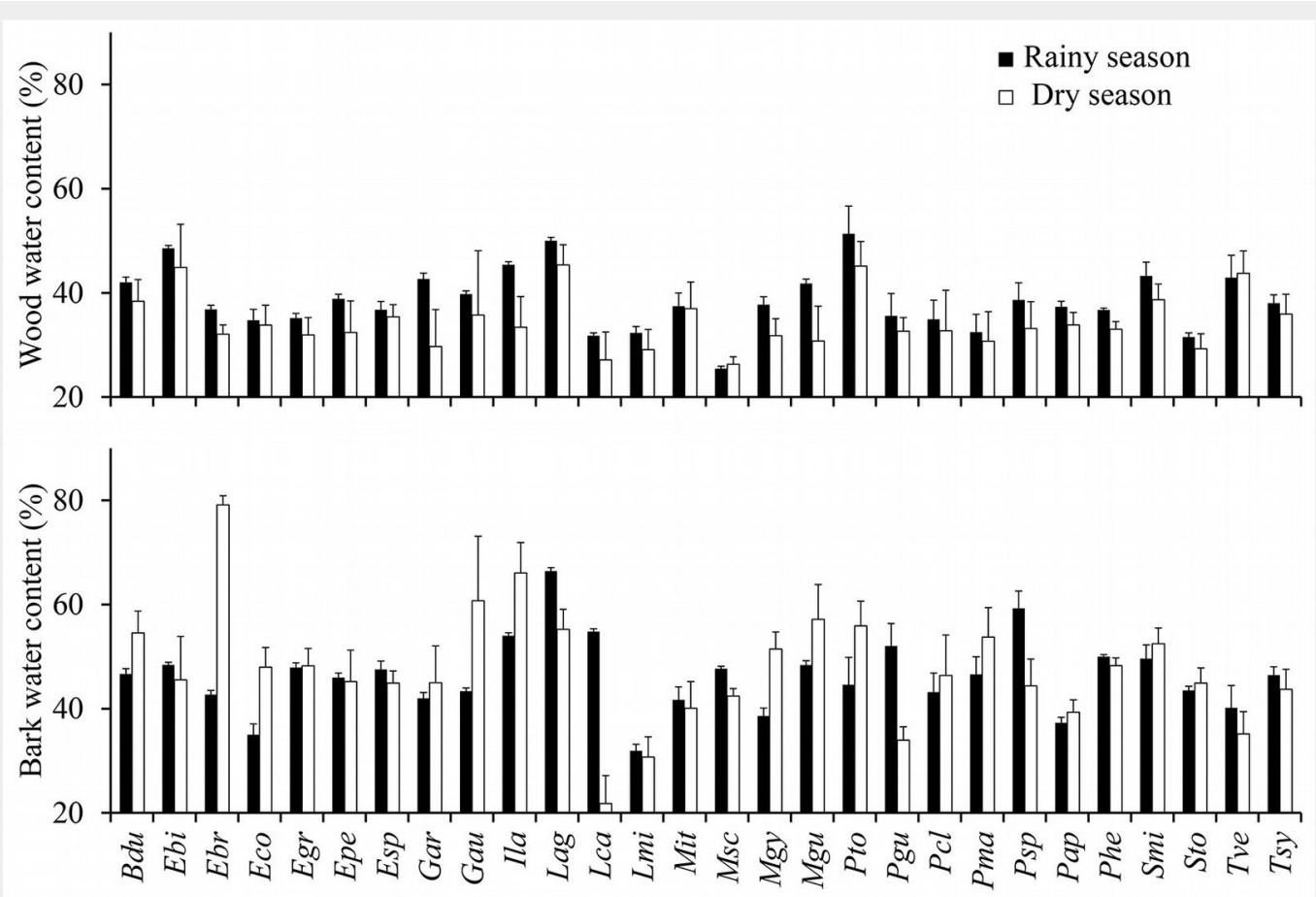

tionship between monthly rainfall (total amount of rainfall over a month) and tree growth, for each month, growth data were pooled across species to obtain the mean monthly growth rate of the trees.

\section{Statistical analysis}

An analysis of variance (ANOVA) under the assumption of a completely randomized design was used for data analysis. Pearson's coefficients were calculated for the relationship between monthly rainfall and tree growth, water content and tree diameter, and between tree growth and stem water content and wood density. All statistical analyses were performed with the SAEG 9.0 statistical package from the Federal University of Viçosa (Brazil).

\section{Results and discussion}

\section{Climate data}

In 2006, total annual rainfall was 2448 $\mathrm{mm}$, which was quite close to the historical mean $(2420 \mathrm{~mm})$ for central Amazonia (Malhi \& Wright 2004). Rainfall was less than $100 \mathrm{~mm} \mathrm{month}^{-1}$ in the drought season, from August to October. February, April, May and November were the rainiest months ( 250 to $300 \mathrm{~mm}^{\text {month }}{ }^{-1}$ ). The average temperature was $25.1^{\circ} \mathrm{C}$, with an average annual minimum of $22.6{ }^{\circ} \mathrm{C}$ and a mean maximum of $28.1^{\circ} \mathrm{C}$. In the driest months, the minimum and maximum temperatures were 23.3 and $30.0{ }^{\circ} \mathrm{C}$, respectively. As expected, the monthly mean cumulative PAR was higher in the driest months, when it was above $30 \mathrm{~mol} \mathrm{~m}^{-2}$ day $^{-1}$.

\section{Wood and bark water content}

In most of the tree species (26 out of 28), trees had stem wood water content higher in the rainy season than in the dry season, tent of the 28 tree species ranged from but several species showed an opposite $25.5 \%$ ( $M$. scleroxylon) to $51.4 \%$ ( $P$. tomenpattern for the water content of the bark tosa), while bark water content varied (Fig. 1). On average, wood water content from 31.9\% (L. micrantha) to 66.4\% (L. agwas $38.3 \%$ in the rainy season and $34.2 \%$ in gregatum - Fig. 1 ). In the dry season, the the dry season $(p=0.000, F=20.4$ - Fig. lowest wood water content was observed 2a).

in M. scleroxylon (26.3\%), and the highest in During the rainy season, wood water con- L. aggregatum (45.4\%). On the other hand,
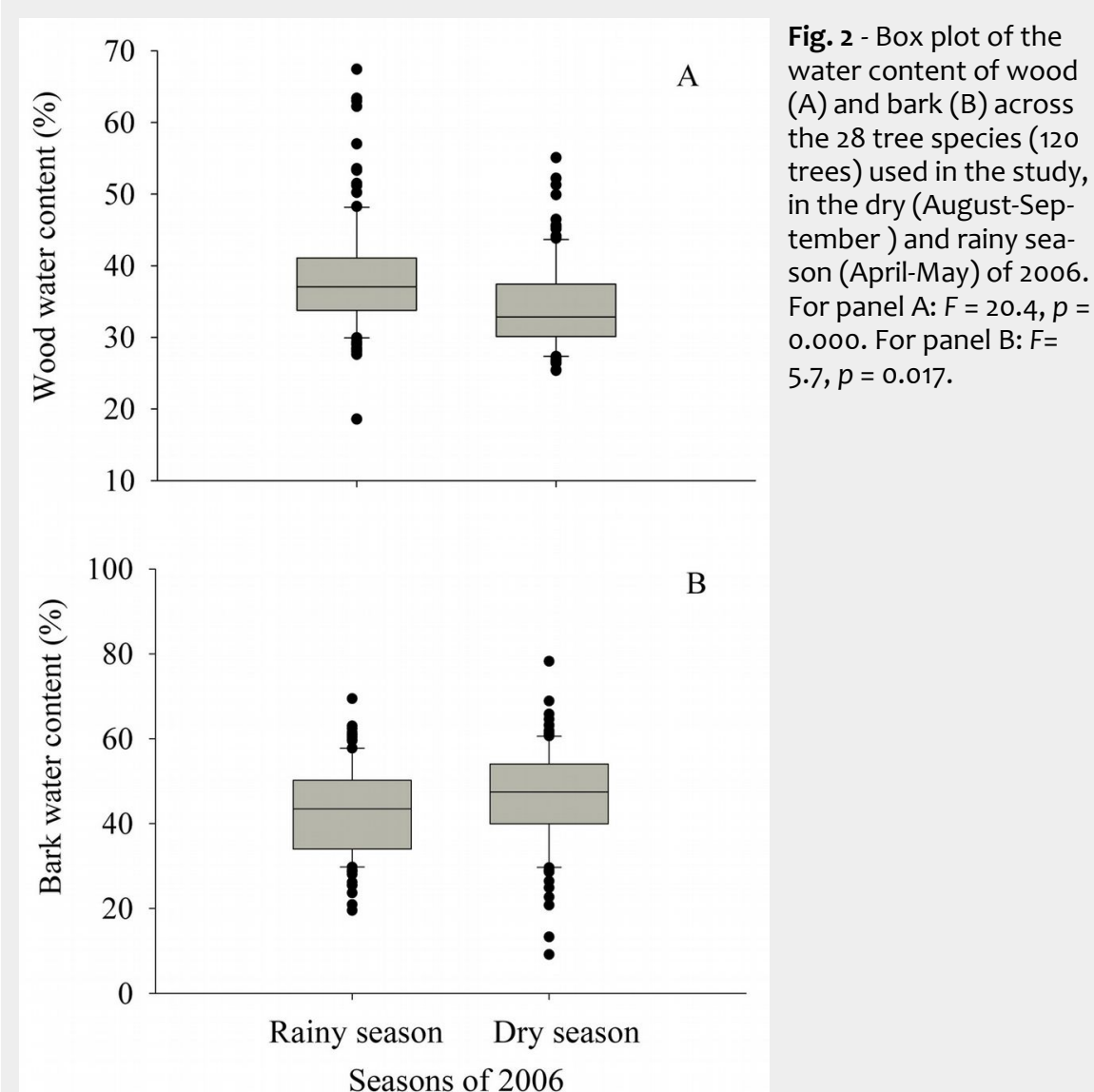
Fig. 3 - Relationship between tree growth and monthly rainfall across the 28 studied species. The black diamond indicates a negative value (see text for discussion). Mean tree growth in diameter was 0.17 $\mathrm{mm}$ month $^{-1}$. Each data point represents the mean growth rate of the 120 sampled trees in a given month of 2006 .

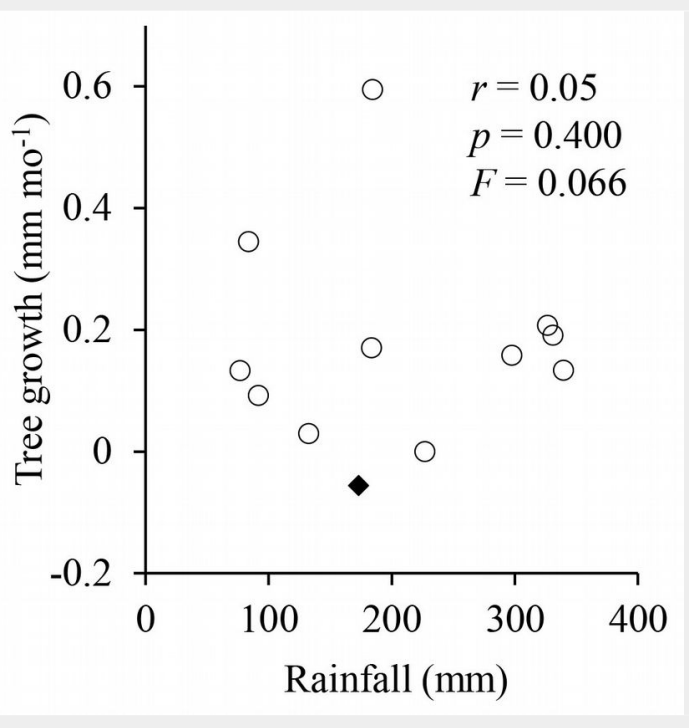

mean bark water content was higher in the dry season $(46.1 \%)$ than in the wet one (42.7\%, $p=0.017, F=5.7$ - Fig. 2b). Trees from several species (e.g., E. bracteosa, I. laurina and G. augusta) had higher bark water content in the dry season than in the rainy season.

The stem wood water contents recorded in this study are within the range found by other researchers (Suzuki 1999, Osunkoya et al. 2007). Osunkoya et al. (2007) found wood water contents varying from 30\% (Shorea parviflora) to 50\% (Dillenia excelsa, Goniothalamus tapis and Glochidion rubrum). In Borneo, in a study involving 286

species, Suzuki (1999) found wood water contents ranging from 26 to $76 \%$. In Amazonian trees, Nogueira et al. (2008) reported wood water content in the range of 22 to $67 \%$ (mean of $33.9 \%$ ), with moisture increasing toward the tip of the tree. Variations in water content of wood and bark have been attributed to environmental and phylogenetic factors, with higher water contents often associated with thicker barks (Rossel et al. 2014). In temperate and tropical forests, tree water content of poles and branches can vary seasonally (Gibbs 1958, Chapotin et al. 2006). In the dry season, and during the driest and warmest

Fig. 4 - Relationship between water content of wood (solid circles) and bark (empty squares) and tree diameter measured at $1.3 \mathrm{~m}(\mathrm{DBH})$, in the rainy season $(A)$ and dry season

(B) of 2006. Each data point represents one tree. For panel A: $F=0.00$ (bark) and $F=0.23$ for wood; $p=0.479$ (bark) and $p=0.315$ for wood. For panel B: $F=1.48$ (bark) and $F=0.00$ for wood; $p=0.112$ (bark) and $p=$ 0.483 for wood.

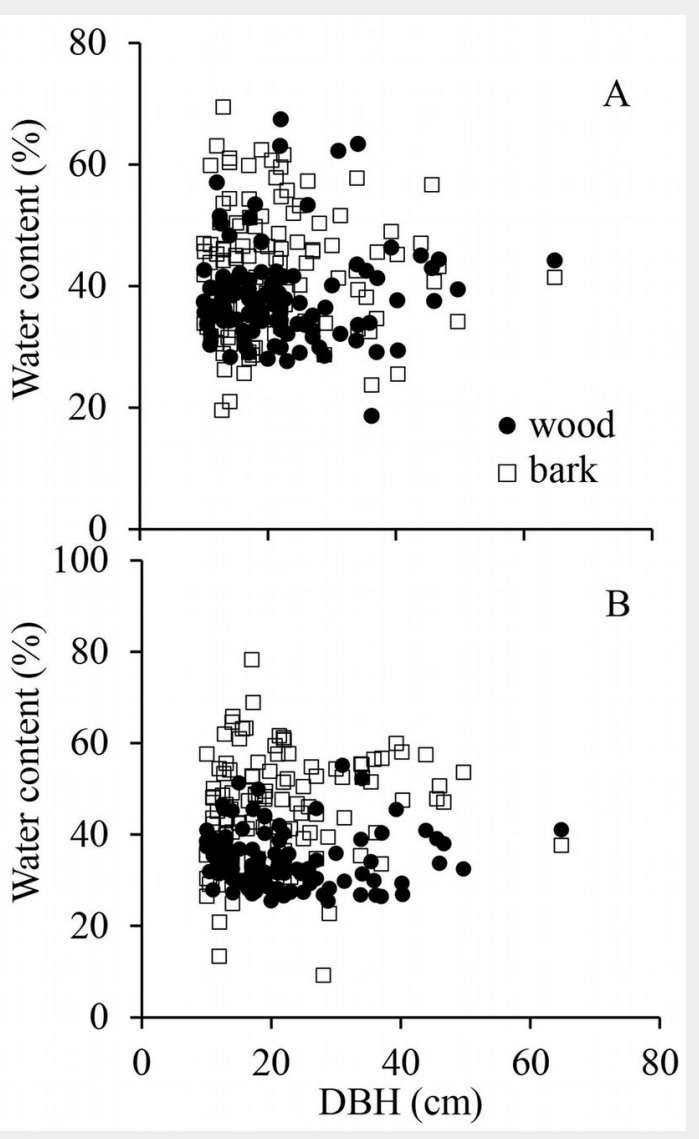

periods of the day, transpiration increases (De Schepper et al. 2012, Marenco et al. 2014), which may explain the lower water content of the stem wood in the dry season (Fig. 2). This is because the pole shrinks as the water stored in the whole tree, particularly in the pole and branches, is used for transpiration. For example, under the severe stressful conditions of tropical dry forests, the stem diameter of baobab trees (Adansonia spp.) can reversibly contract up to $3 \mathrm{~cm}$ by the end of the dry season (Chapotin et al. 2006). At night and during the rainy season, the stem rehydrates and the cycle starts over again, which leads to diurnal and seasonal fluctuations in pole diameter (Gibbs 1958, Chapotin et al. 2006, Vergeynst et al. 2014).

Contrary to our initial expectations, the bark water content of most trees was either equal or higher in the dry season than in the rainy season (Fig. 1). One explanation can be related to leaf phenology of trees in central Amazonia, since production of leaves and bark water content seem to be interrelated (Clark \& Gibbs 1957, Rossel et al. 2014). In central Amazonia the production of litter tends to increase in the dry season (Luizão \& Schubart 1987), which suggests that the production of new leaves can follow a similar pattern (Doughty \& Goulden 2008). It has been postulated that stem rehydration is associated with flushing or flowering in tropical dry forests (Borchert 1994). The bark often has higher water content than the wood as a result of accumulation of osmotically active products (De Schepper et al. 2010). Our results are in agreement with those reported by Gibbs (1958), who found that the water content of the bark can increase when the water content of the wood declines.

On a mass basis, the wood has less water content than the bark because of its main cellular components. Although the sapwood contains parenchyma tissue which can easily expand, the xylem conduits are less prone to contraction and expansion. Indeed, the mature xylem can contract and expand involving elastic deformation (reversible change in shape), but with little exchange of water with the adjacent tissue (Irvine \& Grace 1997). On the other hand, the living components of the bark (phellogen, vascular cambium, phelloderm) may dilate in response to hydration due to the presence of osmotically-active compounds, such as sugars and amino acids. Thus, it seems plausible to conclude that most of the pole contraction occurs in the bark and associated living tissues, such as the sapwood parenchyma (Molz \& Klepper 1973, Zweifel et al. 2000, De Schepper et al. 2012). Therefore, in this work, the rainfall effect on the stem water content could be attributed to a high transpiration rate of the forest canopy in the dry season.

Across species there was no correlation between tree growth in diameter and monthly rainfall throughout the year $(p=$ $0.400, r=0.05, F=0.066-$ Fig. 3$)$. This fin- 
ding contradicts our initial expectation on the effect of rainfall on tree growth in central Amazonia. Thus, our results support the hypothesis that in central Amazonia, the typical mild dry season is not too intense to cause detectable reduction in tree growth.

Tree growth was faster in some species (e.g., I. laurina, S. micranthum, and $T$. venusta) than in others (e.g., G. augusta, $M$. itauba, and T. sylvestre - Tab. 1). This was expected, taken into account the wide biodiversity found in the Amazon. On average, growth rate was $0.17 \mathrm{~mm}^{\text {month }}{ }^{-1}$. This value is lower than those observed in eastern Amazonia (about $0.30 \mathrm{~mm} \mathrm{month}^{-1}$ ), but it is within the range of growth rates reported for central Amazonia, from 0.1 to 0.2 $\mathrm{mm}$ month $^{-1}$ (Wagner et al. (2014). Although from a theoretical point of view it is not possible to record negative growth rates in trees, some trees shrank markedly during the dry season. This explains the negative point (diamond) showed in Fig. 3, and the high variation in tree growth when monthly rainfall was below $200 \mathrm{~mm}$, as the root system of trees can differ in their capability to uptake water from the deep layers of the soil during the drought season.

Irrespective of the season, we did not find any significant relationship between tree size, expressed as $\mathrm{DBH}$, and water content (Fig. 4). At first glance this finding seems to be unexpected because large trees endure more intense transpiration at the hottest times of the day, as they are more exposed to high irradiance and air turbulence above the forest canopy (e.g., wind and thinner boundary layer that allow transpiration to increase). The absence of an effect of tree size on stem water content suggests that large trees are able to uptake water from the deepest layer of the soil profile (Markewitz et al. 2010), which allows them to keep the stem water content at similar levels as those recorded in smaller trees. However, because of their prominence in the forest canopy, large trees are more prone to diurnal and seasonal variations in diameter (Simonneau et al. 1993, Chapotin et al. 2006), which seems to occur without affecting the pole water content (Fig. 4). That is, during the periods of intense transpiration the pole volume is reduced in the same proportion as that of the amount of water stored in the pole, which keeps water content constant.

Water-induced expanding and shrinking of poles pose a major challenge for accurate determination of tree growth in diameter (Baker et al. 2002, Sheil 1997). Substantial reduction in stem water content during the dry season usually leads to stem shrinkage. It has been estimated that tree diameter may decrease up to $8 \%$ as a result of changes in tree water content (Pastur et al. 2007). A measurement error of $1 \%$ in tree diameter can lead to underestimation (or overestimation) of the total biomass by about 4.0 ton $\mathrm{ha}^{-1}$, assuming a mean stem diameter of about $20 \mathrm{~cm}$ and $500-550$ trees

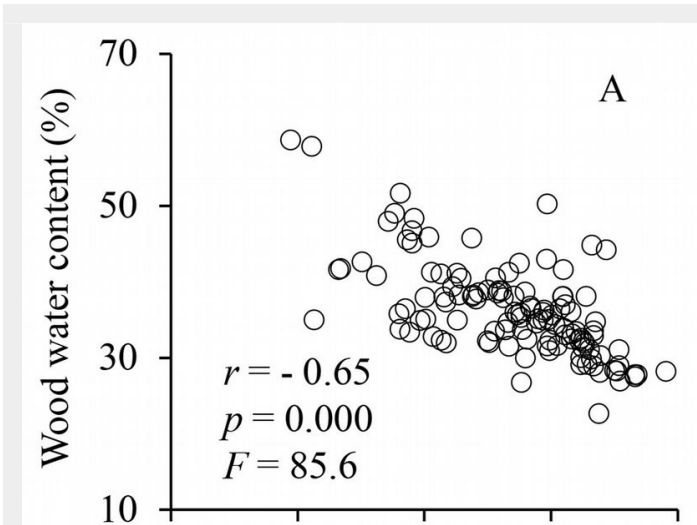

Fig. 5 - Relationship between wood water content and wood density $(A)$ and between tree growth and wood density (B) across the 28 studied species (120 trees). Each data point represents one tree.

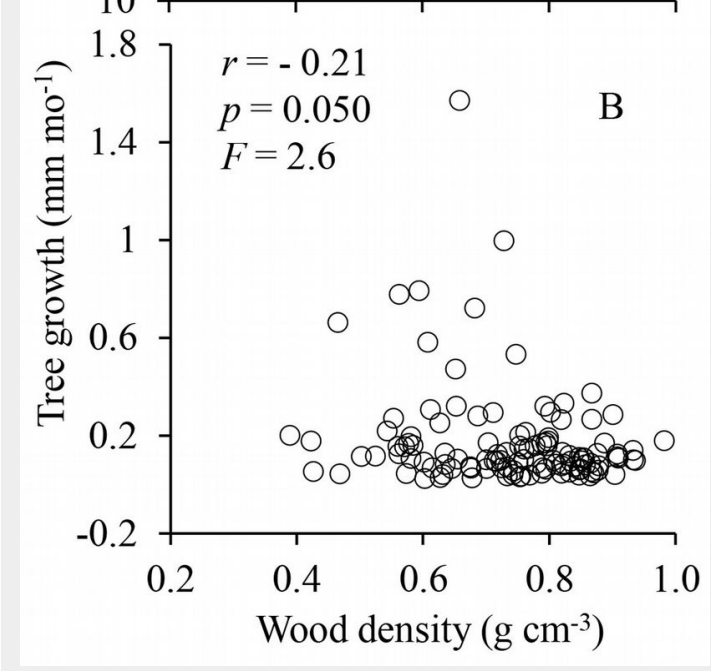

ha ${ }^{-1}$; that is, more than 1.0 Pg (carbon) if extrapolated to the entire Amazon basin. To circumvent the effect of seasonal variation in pole water content, it has been suggested that the best time to determine tree growth using allometric equations is during the dry season, when the pole hydration is minimal (Sheil 1995).

\section{Wood density and water content}

Wood density varied among the 28 species studied, with a mean value of $0.75 \mathrm{~g}$ $\mathrm{cm}^{-3}$ (Tab. 1). Tree species that had higher wood densities were: $P$. macrophylla $(0.91 \mathrm{~g}$ $\left.\mathrm{cm}^{-3}\right)$, P. guianensis $\left(0.89 \mathrm{~g} \mathrm{~cm}^{-3}\right)$ and $M$. scleroxylon $\left(0.89 \mathrm{~g} \mathrm{~cm}^{-3}\right)$. The lowest wood density was found in $P$. tomentosa ( $0.42 \mathrm{~g}$ $\mathrm{cm}^{-3}$ ). Across species, $64.3 \%$ of the species had wood densities above $0.74 \mathrm{~g} \mathrm{~cm}^{-3}$ and only $3.6 \%$ of species had wood densities lower than $0.50 \mathrm{~g} \mathrm{~cm}^{-3}$.

The mean wood density value found in this study is $7 \%$ higher than the mean value previously recorded in the Amazon region, about $0.70 \mathrm{~g} \mathrm{~cm}^{-3}$ (Fearnside 1997, Nogueira et al. 2005). Our mean wood density values are consistent with the common belief that in the Amazon basin, high wood density values are often found in central Amazonia (Baker et al. 2004, Malhi et al. 2004, Nogueira et al. 2008). The mean wood density we found in this study is within the range of those found in other tropical forests, usually from 0.21 to $0.80 \mathrm{~g} \mathrm{~cm}^{-3}$ (Baker et al. 2004, Osunkoya et al. 2007).

A negative correlation $(r=-0.21, p=$
0.050, $F=2.6$ ) was found between wood density and tree growth (Fig. 5). In general, trees with low wood density grow faster than their counterpart with high-density wood (Suzuki 1999, Osunkoya et al. 2007). However, several intrinsic (e.g., genetic make-up of the species) and extrinsic factors (e.g., light and water availability) can affect the growth-wood density relationship; this may explain the low correlation value we found in Fig. 5 .

The wood water content of the studied species negatively correlated with wood density $(r=-0.65, p=0.000, F=85.6-$ Fig. $5 a)$, which is in agreement with the correlation trend reported by others (Santiago et al. 2004, Osunkoya et al. 2007, Nogueira et al. 2008). Denser woods have more space filled with cell walls mainly composed of cellulose, hemicellulose and lignin (less porous wood) and, consequently, less water is stored within the stem wood (Nogueira et al. 2008, McCulloh et al. 2011).

Although the period examined was short (twelve months), the number of trees we measured $(n=120)$ and the closeness of the annual rainfall in 2006 to the historical regional mean ( 2448 vs. $2420 \mathrm{~mm}$, respectively), allowed us to conclude that under the rainfall conditions of a typical year (about $2400 \mathrm{~mm}$ ), the dry season in central Amazonia is not long enough to cause severe soil water depletion at the root zone, which allowed the trees to grow at quite constant rates over the year. More research is needed to elucidate how trees 
of the central Amazon can respond to water availability if the dry season becomes longer and dryer. Also, the ecophysiological implications of the increase of bark water content in the dry season in the central Amazonia remain to be investigated.

\section{Acknowledgements}

The authors thank the Ministry of Science Technology and Innovation (MCTI/INPA), and the Foundation for Research Support of the State of Amazonas (FAPEAM). The Coordination of Improvement of Higher Education Personnel (CAPES) and the National Council for Scientific and Technological Development (CNPq). We also thank the anonymous reviewers for their helpful comments and suggestions.

\section{References}

Baker TR, Affum-Baffoe K, Burslem DFRP, Swaine MD (2002). Phenological differences in tree water use and the timing of tropical forest inventories: conclusions from patterns of dry season diameter change. Forest Ecology and Management 171: 261-274. - doi: 10.1016/S03781127(01)00787-3

Baker TR, Phillips OL, Malhi Y, Almeida S, Arroyo L, Di Fiore A, Erwin T, Killeen TJ, Laurance SG, Laurance WF, Lewis S, Lloyd J, Monteagudo A, Neill DA, Patiño S, Pitman NCA, Silva JNM, Martínez RV (2004). Variation in wood density determines spatial patterns in Amazonian forest biomass. Global Change Biology 10: 545562. - doi: 10.1111/j.1365-2486.2004.00751.x

Borchert R (1994). Soil and stem water storage determine phenology and distribution of tropical dry forest trees. Ecology 75: 1437-1449. - doi: $10.2307 / 1937467$

Cermak J, Kucera J, Bauerle WL, Phillips N, Hinckley TM (2007). Tree water storage and its diurnal dynamics related to sap flow and changes in stem volume in old-growth Douglas-fir trees. Tree Physiology 27: 181-198. - doi: 10.1093/ treephys/27.2.181

Chapotin SM, Razanameharizaka JH, Holbrook NM (2006). Baobab trees (Adansonia) in Madagascar use stored water to flush new leaves but not to support stomatal opening before the rainy season. New Phytologist 169: 549559. - doi: 10.1111/j.1469-8137.2005.01618.x

Chave J, Muller-Landau HC, Baker TR, Easdale TA, Steege H, Webb CO (2006). Regional and phylogenetic variation of wood density across 2456 Neotropical tree species. Ecological Applications 16: 2356-2367. - doi: 10.1890/1051-0761 (2006)016[2356:RAPVOW]2.0.CO;2

Clark J, Gibbs R (1957). Darnley. Studies in tree physiology: IV. Further investigations of seasonal changes in moisture content of certain Canadian forest trees. Canadian Journal of Botany 35: 219-253. - doi: 10.1139/b57-021

De Schepper V, Steppe K, Van Labeke M-C, Lemeu R (2010). Detailed analysis of double girdling effects on stem diameter variations and sap flow in young oak trees. Environmental and Experimental Botany 68: 149-156. - doi: 10.1016/j.envexpbot.2009.11.012

De Schepper V, Van Dusschoten D, Copini P, Jahnke S, Steppe K (2012). MRI links stem water content to stem diameter variations in transpiring trees. Journal of Experimental Botany 63: 2645-2653. - doi: 10.1093/jxb/err445

Doughty CE, Goulden ML (2008). Seasonal patterns of tropical forest leaf area index and $\mathrm{CO}_{2}$ exchange. Journal of Geophysical Research 113: GooBo6. - doi: 10.1029/2007JG000590

Fearnside PM (1997). Wood density for estimating forest biomass in Brazilian Amazonia. Forest Ecology and Management 90: 59-87. - doi: 10.1016/S0378-1127(96)03840-6

Gibbs RD (1958). Patterns in the seasonal water content of trees. In: "The physiology of forest trees" (Thimann KV ed). Ronald Press, New York, USA, pp. 43-69.

Goldstein G, Andrade JL, Meizer FC, Holbrook NM, Cavelier J, Jackson P, Celis A (1998). Stem water storage and diurnal patterns of water use in tropical forest canopy trees. Plant, Cell and Environment 21: 397-406. - doi: 10.1046/j.13 65-3040.1998.00273.x

Hacke UG, Sperry JS, Pockman WT, Davis SD, McCulloh KA (2001). Trends in wood density and structure are linked to prevention of xylem implosion by negative pressure. Oecologia 126: 457-461. - doi: $10.1007 /$ s004420100628

Higuchi N, Dos Santos J, Ribeiro RJ, Minette L, Biot $Y$ (1998). Biomassa da parte aérea da vegetação da floresta tropical úmida de terra-firme da Amazônia brasileira [Biomass of the aboveground vegetation in the terra firme tropical rainforest in the Brazilian Amazon]. Acta Amazonica 28: 153-166. [In Portuguese] - doi: 10.15 90/1809-43921998282166

Irvine J, Grace J (1997). Continuous measurements of water tensions in the xylem of trees based on the elastic properties of wood. Planta 202: 455-461. - doi: $10.1007 /$ s004250050149

Luizão F, Schubart HOR (1987). Litter production and decomposition in a terra-firme forest of Central Amazonia. Experientia 43: 259-265. doi: 10.1007/BF01945549

Malhi Y, Baker T, Phillips OL, Almeida S, Alvarez E, Arroyo L, Chave J, Czimczik Cl, Di Fiore A, Higuchi N, Killeen TJ, Laurance SG, Laurance WF, Lewis SL, Montoya LMM, Monteagudo A, Neill DA, Vargas CAN, Patiño S, Pitman NCA, Quesada CA, Salomão R, Silva JNM, Lezama AT, Martínez RV, Terborgh J, Vinceti B, Lloyd J (2004). The above-ground course wood productivity of 104 Neotropical forest plots. Global Change Biology 10: 563-591. - doi: 10.1111/j.15298817.2003.00778.x

Malhi Y, Wright J (2004). Spatial patterns and recent trends in the climate of tropical rainforest regions. Philosophical Transactions of the Royal Society B - Biological Sciences 359: 311329. - doi: 10.1098/rstb.2003.1433

Marenco RA, Vieira G (2005). Specific leaf area and photosynthetic parameters of tree species in the forest understorey as a function of the microsite light environment in central Amazonia. Journal of Tropical Forest Science 17: 265278. [online] URL: http://www.jstor.org/stable/ 23616574

Marenco RA, Antezana-Vera SA, Gouvêa PRdS, Camargo MAB, Oliveira MFd, Santos JKdS (2014). Physiology of Amazon tree species: photosynthesis, respiration and water relations. Revista Ceres 61: 786-799. [In Portuguese] - doi: 10.1590/0034-730x201461000004
Markewitz D, Devine S, Davidson EA, Brando P, Nepstad DC (2010). Soil moisture depletion under simulated drought in the Amazon: impacts on deep root uptake. New Phytology 187: 592-607. - doi: 10.1111/j.1469-8137.2010.03391.x

McCulloh KA, Meizer FC, Sperry JS, Lachenbruch B, Voelker SL, Woodruff DR, Domec J-C (2011). Comparative hydraulic architecture of tropical tree species representing a range of successional stages and wood density. Oecologia 167: 27-37. - doi: 10.1007/s00442-011-1973-5

Meinzer FC, Johnson DM, Lachenbruch B, McCulloh KA, Woodruff DR (2009). Xylem hydraulic safety margins in woody plants: coordination of stomatal control of xylem tension with hydraulic capacitance. Functional Ecology 23: 922930. - doi: 10.1111/j.1365-2435.2009.01577.x Molz FJ, Klepper B (1973). On the mechanism of water-stress-induced stem deformation. Agronomy Journal 65: 304-306. - doi: 10.2134/agron j1973.00021962006500020035x

Muller-Landau HC (2004). Interspecific and intersite variation in wood specific gravity of tropical trees. Biotropica 36: 20-32. - doi: 10.1111/j.174 4-7429.2004.tboo292.x

Nogueira EM, Nelson BW, Fearnside PM (2005). Wood density in dense forest in central Amazonia, Brazil. Forest Ecology and Management 208: 261-286. - doi: 10.1016/j.foreco.2004.12.007 Nogueira EM, Fearnside PM, Nelson BW (2008). Normalization of the wood density data used in estimates of above-ground live biomass in Amazon forests. Forest Ecology and Management 256: 990-996. - doi: 10.1016/j.foreco.20 08.06 .001

Nortes PA, Pérez-Pastor A, Egea G, Conejero W, Domingo R (2005). Comparison of changes in stem diameter and water potential values for detecting water stress in young almond trees. Agricultural Water Management 77: 296-307. doi: 10.1016/j.agwat.2004.09.034

Osunkoya OO, Sheng TK, Mahmud N-A, Damit N (2007). Variation in wood density, wood water content, stem growth and mortality among twenty-seven tree species in a tropical rainforest on Borneo Island. Austral Ecology 32: 191201. - doi: 10.1111/j.1442-9993.2007.01678.x

Pastur GM, Lencinas MV, Cellini JM, Mundo I (2007). Diameter growth: can live trees decrease? Forestry 80: 83-88. - doi: 10.1093/forestry/ cplo47

Phillips OL, Malhi Y, Vinceti B, Baker T, Lewis SL, Higuchi N, Laurance WF, Núñez Vargas $P$, Martinez RV, Laurance S, Ferreira LV, Stern M, Brown S, Grace J (2002). Changes in growth of tropical forests: evaluating potential biases. Ecological Application 12: 576-587. - doi: 10.18 90/1051-0761(2002)012[0576:CIGOTF]2.0.CO;2 Remorini D, Massai R (2003). Comparison of water status indicators for young peach trees. Irrigation Science 22: 39-46. - doi: 10.1007/ s00271-003-0068-4

Rossel JA, Gleason S, Méndez-Alonzo R, Chang Y, Westoby M (2014). Bark functional ecology: evidence for tradeoffs, functional coordination, and environment producing bark diversity. New Phytologist 201: 486-497. - doi: 10.1111/nph. 12541

Santiago LS, Goldstein G, Meinzer FC, Fisher JB, Machado K, Woodruff D, Jones T (2004). Leaf photosynthetic traits scale with hydraulic con- 
ductivity and wood density in Panamanian forest canopy trees. Oecologia 140: 543-550. - doi: 10.1007/s00442-004-1624-1

Sheil D (1995). A critique of permanent plot methods and analysis with examples from Budongo forest, Uganda. Forest Ecology and Management 77: 11-34. - doi: 10.1016/0378-1127(95) $03583-\mathrm{V}$

Sheil D (1997). Long-term growth and rainfall in a Ugandan moist forest: seasonal rhythms and flexing stems. Commonwealth Forestry Review 76: 121-127. [online] URL: http://www.jstor.org/ stable/42608796

Simonneau T, Habib R, Goutouly JP (1993). Diurnal changes in stem diameters depend upon variations in water content: direct evidence in peach-trees. Journal of Experimental Botany 44: 615-621. - doi: 10.1093/jxb/44.3.615

Stratton L, Goldstein G, Meinzer FC (2000). Stem water storage capacity and efficiency of water transport: their functional significance in a Hawaiian dry forest. Plant, Cell and Environment 23: 99-106. - doi: 10.1046/j.1365-3040.20 $00.00533 . \mathrm{x}$

Suzuki E (1999). Diversity in specific gravity and water content of wood among Bornean tropical rainforest trees. Ecological Research 14: 211224. - doi: 10.1046/j.1440-1703.1999.143301.x

Vergeynst LL, Vandegehuchte MW, McGuire MA, Teskey RO, Steppe K (2014). Changes in stem water content influence sap flux density measurements with thermal dissipation probes.
Trees 28: 949-955. - doi: 10.1007/s00468-014og89-y

Wagner F, Rossi $V$, Aubry-Kientz $M$, Bonal D, Dalitz H, Gliniars R, Stahl, C, Trabucco A, Hrault $B$ (2014). Pan-tropical analysis of climate effects on seasonal tree growth. PLoS ONE 9 (3): e92337. - doi: 10.1371/journal.pone.0092337

Williamson GB, Wiemann MC (2010). Measuring wood specific gravity... correctly. American Journal of Botany 97: 519-524. - doi: 10.3732/ ajb.0900243

Zweifel R, Item H, Häster R (2000). Stem radius changes and their relation to stored water in stems of young Norway spruce trees. Trees 15: 50-57. - doi: 10.1007/s004680000072 